\title{
WHATSAPP FORENSICS: EKSPLORASI SISTEM BERKAS DAN BASIS DATA PADA APLIKASI ANDROID DAN IOS
}

\author{
Ahmad Raf'ie Pratama \\ Jurusan Teknik Informatika, Fakultas Teknologi Industri, Universitas Islam Indonesia \\ Jalan Kaliurang Km.14,5 Sleman, Yogyakarta 55501 \\ ahmad.rafie@uii.ac.id
}

\begin{abstract}
WhatsApp is a multiplatform instant messenger with the most users worldwide by 2013. The popularity of WhatsApp has raised the need of better understanding on how it stores chat archives within the application. This knowledge is useful in term of mobile forensics purposes. In this paper, the latest version of WhatsApp applications in two major platforms, Android and iOS are used in order to explore the file systems and database, to learn where and how the messages and other files are stored, and then to analyze the strength and the weakness of this implementation. The main finding of this research is that WhatsApp uses different file system and database structure in its iOS and Android application. While the database in iOS platform is well structured and makes use of good normalization, the database in Android platform is much simpler and stored as encrypted file within the file system. Furthermore, this research also shows that it is relatively easy to recover all messages history from the database in both platforms; given the Android devices have been rooted but not necessarily jailbreak the iOS devices. Based on this finding, it is possible to develop an application to read WhatsApp database and display it in a more user-friendly format to make forensic activity much easier.
\end{abstract}

Keywords: WhatsApp, Forensics, Database, Android, iOS

\section{PENDAHULUAN}

Dalam dunia telekomunikasi, terdapat dua fitur layanan utama yang selalu ada dan terus berevolusi seiring dengan perkembangan teknologi, suara (voice) dan pesan (message). Dibandingkan dengan layanan suara yang mengharuskan penggunanya untuk terhubung secara bersamaan di waktu yang sama (synchronous), layanan pesan memiliki keunggulan pada keleluasaan untuk bertukar informasi secara kasual, pengguna dapat bertukar pesan kapanpun tanpa harus menunggu lawan komunikasinya siap layaknya pada layanan suara. Layanan pertukaran pesan bukan hanya monopoli dunia telekomunikasi, di dunia jaringan komputer pun layanan pertukaran pesan, atau biasa disebut dengan chat, banyak digunakan untuk berbagai keperluan.

Layanan pesan singkat, atau biasa dikenal dengan istilah SMS (Short Messaging Service) telah digunakan secara luas oleh semua pelanggan telepon seluler, baik di jaringan GSM maupun jaringan CDMA selama beberapa dekade terakhir. Di sisi lain, aplikasi pesan instant berbasis internet pada platform PC juga memiliki segmentasi tersendiri, aplikasi-aplikasi seperti $M i R C$, Yahoo! Messenger, MSN Messenger, ataupun Google Talk juga lazim digunakan sebagai media komunikasi sehari - hari oleh pengguna internet.

Pesatnya perkembangan teknologi informasi dan komunikasi telah melahirkan inovasi baru dalam layanan pertukaran pesan. Beberapa jenis aplikasi pesan singkat baru muncul dengan konsep baru, mereka berjalan di berbagai platform telepon pintar seperti Android, iOS, Blackberry, hingga Windows Phone layaknya layanan SMS namun dengan menggunakan jaringan internet, bukan jaringan telepon seluler sebagai jalur komunikasi utamanya.

Aplikasi - aplikasi seperti WhatsApp, WeChat, Line, KakaoTalk, Blackberry Messenger, hingga Telegram menjadi alternatif baru dalam bertukar pesan dikarenakan kemudahan penggunaannya, di samping tentu saja biaya yang jauh lebih murah jika dibandingkan dengan bertukar 
pesan melalui layanan SMS. Cukup dengan akses ke jaringan internet pada telepon genggam mereka, pengguna dapat berkirim pesan secara bebas kepada siapapun yang juga telah menggunakan aplikasi yang sama. Pengguna tidak perlu mengkhawatirkan tarif lintas operator ataupun internasional layaknya layanan SMS biasa.

Di antara beberapa aplikasi yang ada, WhatsApp merupakan salah satu pioner dan telah mencapai kesuksesannya dengan keberadaan xxx juta pengguna per Januari 2014. Bahkan, per xxx jumlah pesan yang diproses WhatsApp untuk satu harinya telah melebihi peredaran seluruh SMS yang beredar di seluruh dunia untuk waktu yang sama.

Mengingat tingginya popularitas dan tingkat penggunaan WhatsApp saat ini, potensi penyalahgunaannya pun meningkat sebagaimana juga yang telah terjadi pada layanan SMS. Arsip pesan yang tersimpan pada aplikasi WhatsApp yang terpasang di telepon seluler dapat dijadikan bukti digital untuk mengungkap kejahatan - kejahatan yang menggunakan aplikasi ini sebagai media komunikasinya.

Penelitian ini difokuskan pada eksplorasi sistem berkas dan basis data dari aplikasi WhatsApp pada dua platform utama, Android dan iOS. Eksplorasi basis data yang dilakukan bertujuan untuk memetakan dan memberikan gambaran yang menyeluruh mengenai peluang dan tantangan penggalian bukti digital dari arsip pesan WhatsApp yang tersimpan di telepon seluler penggunanya. Penelitian dilakukan dengan menggunakan masing - masing satu perangkat berbasis Android dan satu perangkat berbasis iOS di mana pada keduanya telah terpasang versi WhatsApp terbaru saat penelitian ini dilakukan.

\section{TINJAUAN PUSTAKA}

Penelitian di bidang forensika pesan instan telah banyak dilakukan, di antaranya saat Van Dongen melakukan eksplorasi sistem berkas dari aplikasi Windows Live Messenger 8.0 yang berjalan di platform
Windows PC untuk menggali potensi bukti digital yang bisa ditemukan (2007). Penelitian lain yang juga pernah dilakukan pada kurun waktu yang berdekatan adalah pada beberapa aplikasi pesan instan lainnya, yakni AOL Messenger, Yahoo! Messenger, dan MSN Messenger (Killey, M., Danker, S., \& Rogers, M., 2008) yang juga berjalan pada platform PC, terutama yang berbasis sistem operasi Windows. Khusus untuk aplikasi Yahoo! Messenger yang notabene sangat populer digunakan di Indonesia pada kurun waktu tersebut, terdapat penelitian lainnya yang juga telah dilakukan dalam rangka mengevaluasi dan menemukan jejak data dari berbagai macam fitur yang disediakan oleh aplikasi pesan instan tersebut (Levendoski et.al, 2011).

Sementara itu, penelitian lainnya tentang forensika aplikasi pesan instan sejenis yang berjalan pada perangkat bergerak juga telah pernah dilakukan, di mana aplikasi AIM, Yahoo! Messenger dan Google Talk yang berjalan pada Apple iPhone menjadi objek eksplorasinya (Husain \& Sridhar, 2010). Meskipun telah berpindah dari platform PC ke perangkat bergerak, penelitian ini masih mengeksplorasi aplikasi pesan instan generasi pertama yang masih menggunakan akun tersendiri dan belum mengintegrasikan nomer telepon seluler pengguna sebagai identitasnya

Seiring dengan meredupnya popularitas aplikasi pesan instan generasi pertama ini yang juga diiringi tumbuh suburnya aplikasi pesan instan generasi baru, beberapa penelitian lain juga lantas dilakukan seperti yang dilakukan oleh Mahajan, et.al (2013) yang mengeksplorasi aplikasi WhatsApp dan Viber, serta penelitian oleh Thakur (2013) yang difokuskan pada aplikasi WhatsApp. Kedua penelitian ini dilakukan pada perangkat bergerak berbasis sistem operasi Android.

Meskipun beberapa penelitian di atas telah dilakukan, masih terdapat banyak ruang yang belum dieksplorasi secara mendalam atau bahkan belum tersentuh sama sekali. Di antara semua aplikasi pesan instan generasi baru yang ada, tidak dapat 
dipungkiri WhatsApp merupakan pilihan utama dengan jumlah pengguna terbanyak. Namun demikian, popularitas WhatsApp yang begitu tinggi tidak bisa dilepaskan dari ketersediaannya pada beberapa platform perangkat bergerak yang berbeda, di mana selain Android masih ada platform iOS yang menjadi dua pemain utama di dunia. Kebanyakan penelitian yang dilakukan masih terbatas pada satu platform perangkat bergerak saja, karenanya penelitian yang dilakukan akan memberikan gambaran yang lebih baik jika eksplorasi dilakukan pada beberapa platform sekaligus pada waktu yang bersamaan.

Selain itu, perkembangan aplikasi di perangkat bergerak yang lebih cepat jika dibandingkan dengan di platform PC menuntut proses eksplorasi ulang setiap kali perubahan (update) aplikasi dilakukan oleh pengembangnya. Pembaharuan aplikasi seringkali melibatkan hal - hal seperti perubahan sistem berkas, struktur basis data, hingga penambahan fitur - fitur keamanan (semisal enkripsi sistem berkas atau basis data) pada aplikasi yang bersangkutan.

\section{EKSPLORASI PADA ANDROID}

Dalam penelitian ini, eksplorasi pada platform Android dilakukan dengan menggunakan perangkat uji telepon pintar iOcean X7 Turbo produksi Cina dengan spesifikasi perangkat keras prosesor MT6589 Quad Core 1,5 GHz, RAM 1GB, internal storage $2 G B$, external memory $8 G B$, dan bentang layar 5" dengan resolusi Full HD 1920x1080. Adapun dari sisi perangkat lunaknya terpasang sistem operasi Android 4.2.1 Jelly Bean dan WhatsApp versi 2.11.186.

Proses eksplorasi dimulai dengan menghubungkan perangkat uji ke sebuah PC dengan mode USB storage untuk dilihat struktur sistem berkasnya. Dari proses eksplorasi ditemukan sebuah folder WhatsApp tersimpan dalam memori eksternal gambar 1 memperlihatkan bagaimana semua media tersimpan dengan struktur yang rapi, baik itu berupa gambar, audio, video, pesan suara, hingga foto profil dari pengguna lainnya. Sementara itu, ditemukan juga sebuah folder yang diduga berisikan arsip pesan dalam folder lain sebagaimana dapat dilihat pada gambar 2 . Setelah diverifikasi lebih lanjut, ditemukan basis data ini tersimpan dalam format terenkripsi sehingga tidak dapat dibaca isi di dalamnya. Adapun rangkuman keseluruhan folder yang ditemukan beserta keterangan untuk masing-masingnya dapat dilihat pada tabel 1 .

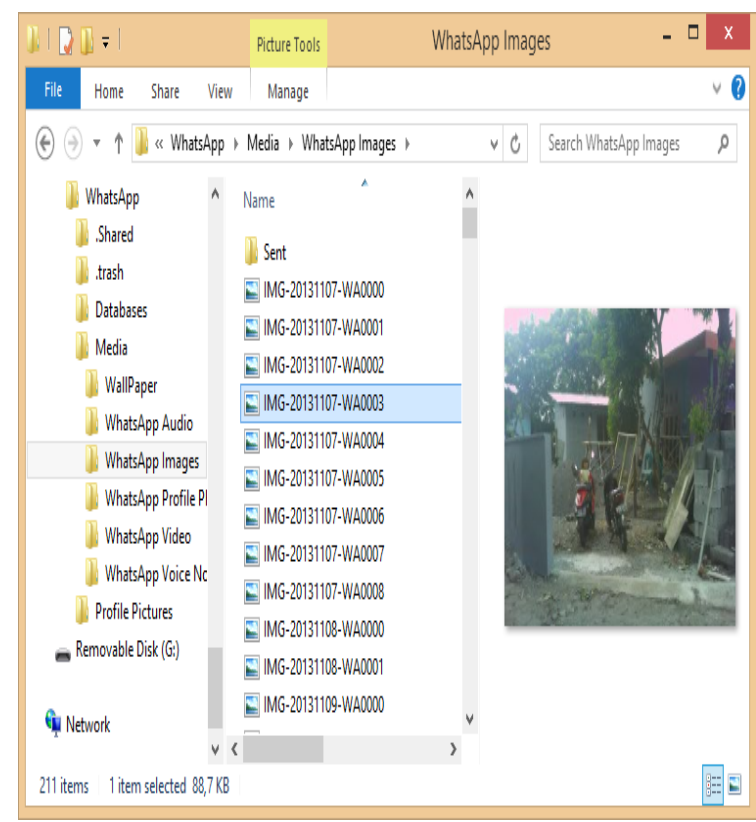

Gambar 1. Sistem berkas penyimpanan media pada WhatsApp di platform Android

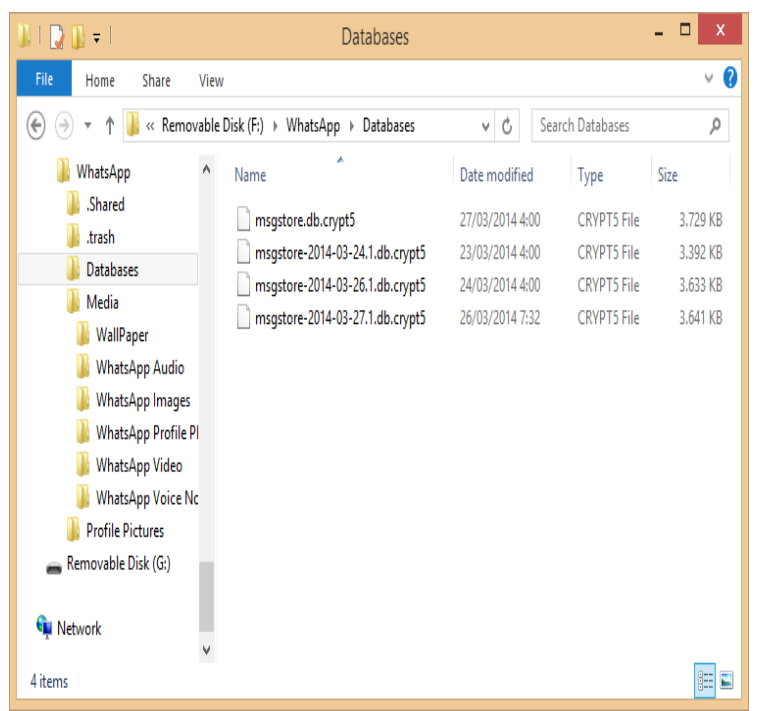

Gambar 2. Sistem berkas penyimpanan basis data pada WhatsApp di platform Android 
Tabel 1. Sistem berkas yang ditemukan pada WhatsApp di platform Android

\begin{tabular}{|c|c|c|}
\hline No & Lokasi & Keterangan \\
\hline 1 & Shared & Kosong \\
\hline 2 & \.trash & Kosong \\
\hline 3 & Database & $\begin{array}{l}\text { Database } \\
\text { arsip } \\
\text { terenkripsi }\end{array}$ \\
\hline 4 & MedialWallPaper & $\begin{array}{l}\text { Wallpaper } \\
\text { Chat }\end{array}$ \\
\hline 5 & $\begin{array}{l}\text { MedialWhatsApp } \\
\text { Audio }\end{array}$ & Audio masuk \\
\hline 6 & $\begin{array}{l}\text { MedialWhatsApp } \\
\text { AudiolSent }\end{array}$ & Audio keluar \\
\hline 7 & $\begin{array}{l}\text { IMedialWhatsApp } \\
\text { Images }\end{array}$ & $\begin{array}{l}\text { Gambar } \\
\text { masuk }\end{array}$ \\
\hline 8 & $\begin{array}{l}\text { IMedialWhatsApp } \\
\text { Images'Sent }\end{array}$ & $\begin{array}{l}\text { Gambar } \\
\text { keluar }\end{array}$ \\
\hline 9 & $\begin{array}{l}\text { MedialWhatsApp } \\
\text { Profile Photos }\end{array}$ & $\begin{array}{l}\text { Foto profil } \\
\text { pengguna }\end{array}$ \\
\hline 10 & $\begin{array}{l}\text { IMedialWhatsApp } \\
\text { Video }\end{array}$ & Video masuk \\
\hline 11 & $\begin{array}{l}\text { UMedialWhatsApp } \\
\text { Video\Sent }\end{array}$ & Video keluar \\
\hline 12 & $\begin{array}{l}\text { WedialWhatsApp } \\
\text { Voice Notes }\end{array}$ & $\begin{array}{l}\text { Pesan suara } \\
\text { masuk }\end{array}$ \\
\hline 13 & $\begin{array}{l}\text { WedialWhatsApp } \\
\text { Voice Notes'Sent }\end{array}$ & $\begin{array}{l}\text { Pesan suara } \\
\text { keluar }\end{array}$ \\
\hline 14 & Profile Pictures & $\begin{array}{l}\text { Foto profil } \\
\text { pengguna } \\
\text { lain }\end{array}$ \\
\hline
\end{tabular}

Proses eksplorasi dilanjutkan dengan melakukan proses rooting pada perangkat uji dan memasang aplikasi khusus agar dapat mengakses sistem berkas tersembunyi dan terlindungi di mana sistem operasi dan seluruh aplikasi terpasang disimpan. Pada penelitian ini, digunakan aplikasi Root Browser* yang dapat diunduh secara gratis di Google Play Store. Hasil eksplorasi lebih lanjut yang dilakukan berhasil menemukan basis data yang tidak terenkripsi di simpan pada sistem berkas tersembunyi dan terlindungi ini di lokasi /data/data/com/whatsapp/database seperti yang tampak pada gambar 3. Adapun rangkuman seluruh sistem berkas yang ditemukan tampak pada tabel 2.

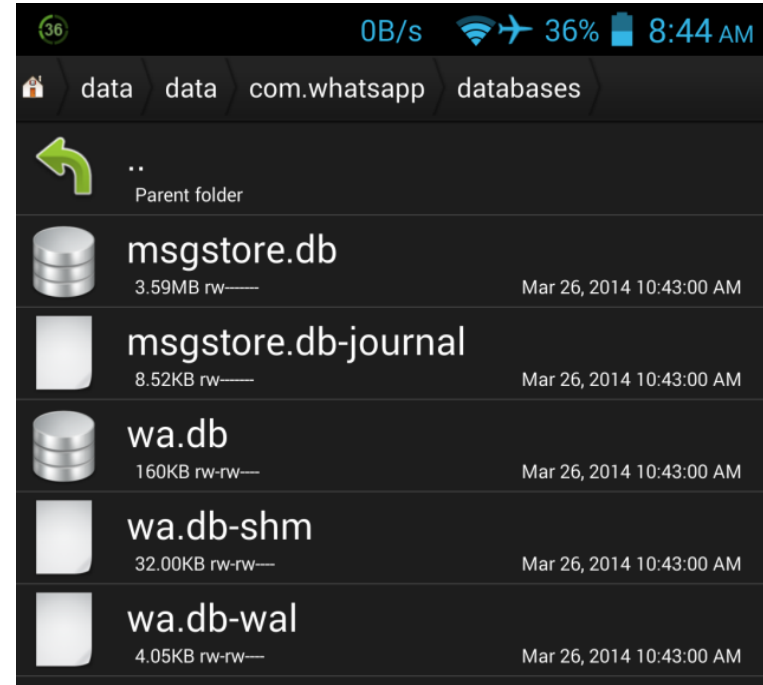

Gambar 3. Basis data yang tidak terenkripsi di dalam sistem berkas tersembunyi dan terlindungi pada WhatsApp di platform Android

Tabel 2. Sistem berkas tersembunyi dan terlindungi yang ditemukan pada WhatsApp di platform Android

\begin{tabular}{|c|c|c|}
\hline No & Lokasi & Keterangan \\
\hline 1 & \app_Keys & Kosong \\
\hline 2 & Vache & $\begin{array}{l}\text { Cache DNS dan } \\
\text { beberapa lainnya }\end{array}$ \\
\hline 3 & \databases & $\begin{array}{l}\text { Database arsip dalam } \\
\text { format tidak terenkripsi }\end{array}$ \\
\hline 4 & Viles & $\begin{array}{l}\text { Tipe akun, Emoji } \\
\text { (emoticon), Expiration } \\
\text { Date, dan beberapa file } \\
\text { lainnya }\end{array}$ \\
\hline 5 & yiles\Avatars & $\begin{array}{l}\text { Avatar/Profile Photos } \\
\text { dari semua pengguna } \\
\text { lain dengan format } \\
\text { penamaan } \\
\text { no.hp@s.whatsapp.net.j } \\
\text { untuk pengguna } \\
\text { individual dan } \\
\text { no.hp.admin- } \\
\text { kode.grup@g.us.j untuk } \\
\text { grup. }\end{array}$ \\
\hline 6 & Yiles\Logs & $\begin{array}{l}\text { Beberapa log dari } \\
\text { aplikasi dan server } \\
\text { WhatsApp }\end{array}$ \\
\hline 7 & Vib & $\begin{array}{l}\text { Beberapa library yang } \\
\text { dibutuhkan dalam } \\
\text { format .so }\end{array}$ \\
\hline 8 & \shared_prefs & $\begin{array}{l}\text { Konfigurasi dan } \\
\text { beberapa berkas } \\
\text { pengaturan lain dalam } \\
\text { format XML }\end{array}$ \\
\hline
\end{tabular}


Selanjutnya, eksplorasi dilanjutkan pada basis data yang ditemukan. Format basis data yang digunakan oleh WhatsApp adalah SQLite versi 3, karenanya diperlukan bantuan aplikasi pembaca basis data SQLite untuk dapat melihat isi di dalamnya. Pada penelitian ini aplikasi yang digunakan adalah SQLiteStudio versi 2.1.5 dan Navicat for SQLite Trial edition versi 11.0.17. Dari eksplorasi awal, didapatkan dua basis data yang ditemukan memiliki beberapa tabel seperti yang tampak pada gambar 4 .

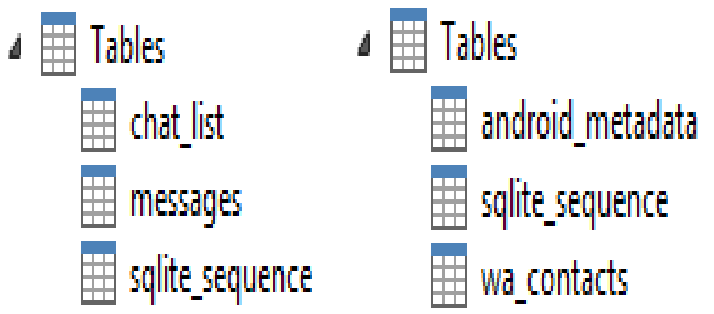

Gambar 4. Daftar tabel pada basis data msgstore.db (kiri) dan basis data wa.db (kanan)

\begin{tabular}{|c|c|c|c|c|c|c|c|c|}
\hline$\#$ & Name & Data type & $\mathbf{P}$ & F U & U H & N & c & Default value \\
\hline 1. & _id & INTEGER & 2 & & & & & MULL \\
\hline 2 & key_remote_jid & TEXT & & & & (6) & & KWLLL \\
\hline 3 & key_from_me & INTEGER & & & & & & NULL \\
\hline 4 & key_id & TEXT & & & & (6) & & ALULL \\
\hline 5 & status & INTEGER & & & & & & MULL \\
\hline 6 & needs_push & INTEGER & & & & & & NMULL \\
\hline 7 & data & TEXT & & & & & & MULLL \\
\hline 8 & timestamp & INTEGER & & & & & & KULL \\
\hline 9 & media_url & TEXT & & & & & & MULL \\
\hline 10 & media_mime_type & TEXT & & & & & & WHLL \\
\hline 11 & media_wa_type & TEXT & & & & & & NULL \\
\hline 12 & media_size & INTEGER & & & & & & NULL \\
\hline 13 & media_name & TEXT & & & & & & NULL \\
\hline 14 & media_hash & TEXT & & & & & & MULL \\
\hline 15 & media_duration & INTEGER & & & & & & NULLL \\
\hline 16 & origin & INTEGER & & & & & & MULLL \\
\hline 17 & latitude & REALL & & & & & & MULLL \\
\hline 18 & longitude & REÁL & & & & & & MULLL \\
\hline 19 & thumb_image & TEXT & & & & & & AUILL \\
\hline 20 & remote_resource & TEXT & & & & & & MULL \\
\hline 21 & received_timestamp & INTEGER & & & & & & MULL \\
\hline 22 & send_timestamp & INTEGER & & & & & & $A L / L$ \\
\hline 23 & receipt_server_timestamp & INTEGER & & & & & & NULLL \\
\hline 24 & receipt_device_timestamp & INTEGER & & & & & & AULLL \\
\hline 25 & raw_data & BLOB & & & & & & NULL \\
\hline 26 & recipient_count & INTEGER & & & & & & MULL \\
\hline
\end{tabular}

Gambar 5. Struktur tabel messages pada basis data msgstore.db di platform Android
Struktur tabel messages pada basis data msgstore.db yang menyimpan seluruh arsip pesan dapat dilihat pada gambar 5, sementara struktur tabel wa_contacts pada basis data $w a . d b$ yang menyimpan seluruh kontak pengguna lain dapat dilihat pada gambar 6. Masing - masing field menyimpan informasi sesuai dengan nama yang dimiliki, namun demikian untuk keperluan forensika tingkat dasar, dapat dicermati beberapa field tertentu dengan melakukan SQL query seperti yang tampak pada gambar 7 sehingga menghasilkan arsip percakapan seperti yang dapat dilihat pada gambar 8 .

\begin{tabular}{|c|c|c|c|c|c|c|c|c|}
\hline$\#$ & Name & Data type & $\mathbf{P}$ & $F$ & U H & N N & C & Default value \\
\hline 1. & _id & INTEGER & 2) & & & & & KMULL \\
\hline $2 \mathrm{i}$ & jid & TEXT & & & & (6) & & MULL \\
\hline $3 i$ & is_whatsapp_user & BOOLEAN & & & & (6) & & MULL \\
\hline $4:$ & status & TEXT & & & & & & NLILL \\
\hline $5 r$ & number & TEXT & & & & & & MULL \\
\hline $6 r$ & raw_contact_id & INTEGER & & & & & & WILL \\
\hline 7 & display_name & TEXT & & & & & & WIILL \\
\hline 8 & phone_type & INTEGER & & & & & & NULLL \\
\hline 9 & phone_label & TEXT & & & & & & NWLLL \\
\hline 10 & unseen_msg_count & INTEGER & & & & & & WILL \\
\hline $11 \mathrm{~F}$ & photo_ts & INTEGER & & & & & & NIILL \\
\hline 12 & thumb_ts & INTEGER & & & & & & $M U L L$ \\
\hline 13 & photo_id_timestamp & INTEGER & & & & & & $M U L L$ \\
\hline 14 & given_name & TEXT & & & & & & NILL \\
\hline 15 & family_name & TEXT & & & & & & MULL \\
\hline $16 \sqrt{4}$ & wa_name & TEXT & & & & & & MULL \\
\hline $17 s$ & sort_name & TEXT & & & & & & $M U L L$ \\
\hline $18=$ & status_timestamp & INTEGER & & & & & & NULL \\
\hline
\end{tabular}

Gambar 6. Struktur tabel wa_contacts pada basis data $w a . d b$ di platform Android

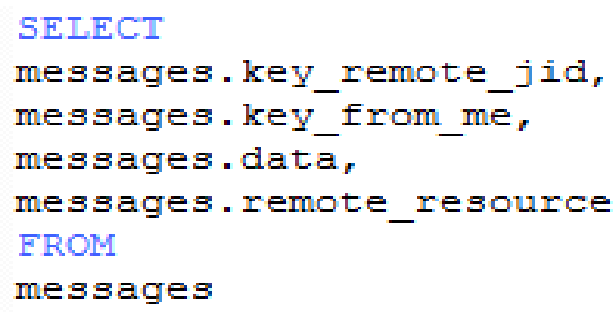

Gambar 7. Contoh SQL Query untuk menyaring arsip percakapan pada tabel messages 


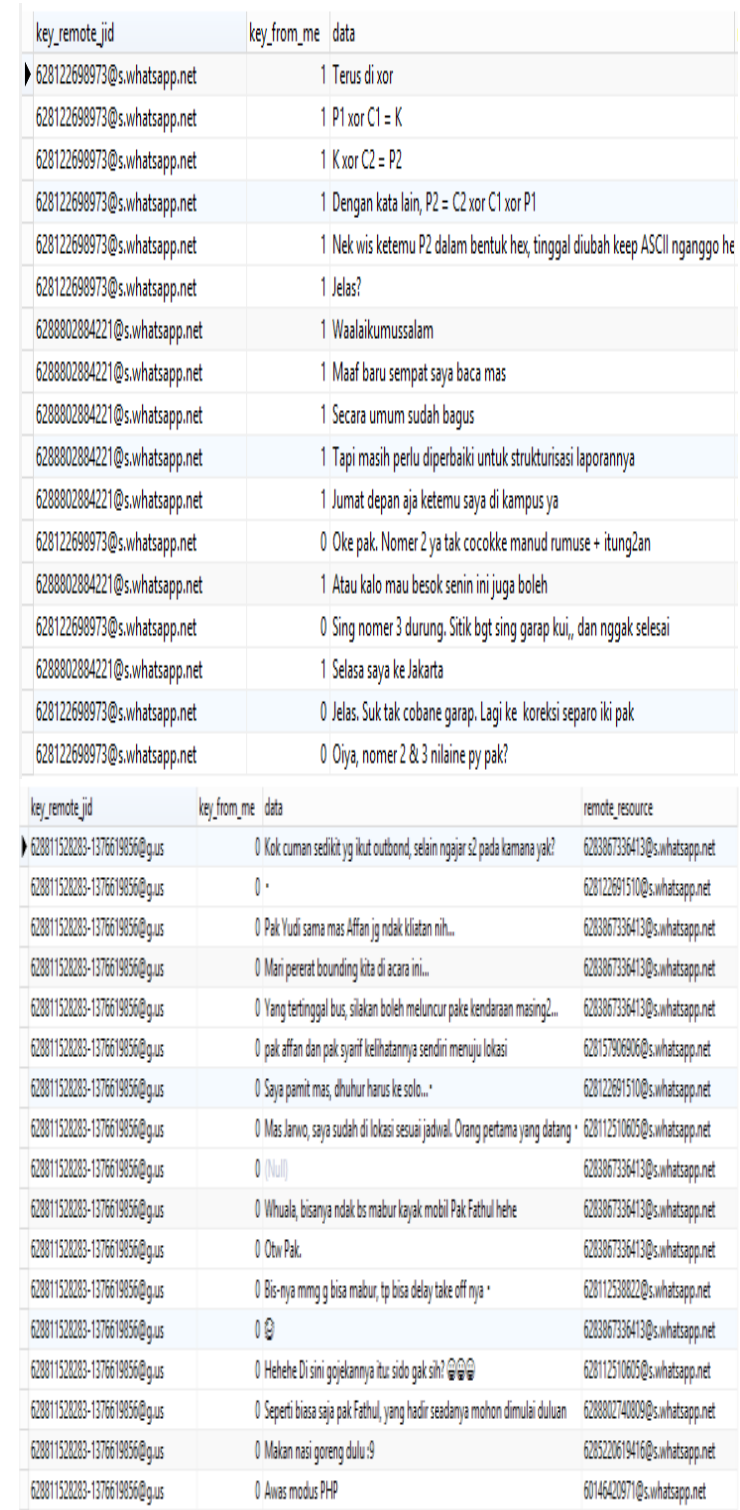

Gambar 8. Hasil SQL Query table messages berupa arsip percakapan individual (atas) dan grup (bawah) pada WhatsApp di platform Android

Dari hasil eksplorasi ditemukan bahwa struktur basis data pada platform Android, field key_remote_jid berisikan ID pengguna lain yang menjadi lawan bicara dalam format standard WhatsApp yang menyerupai alamat email, yakni <no.hp>@s.whatsapp.net untuk percakapan individual, atau <no.hp.admin>-<kode.grup>@g.us untuk percakapan grup. Khusus untuk percakapan grup, ID pengirim pesan akan menempati field lain, yakni remote_resource yang dikosongkan untuk percakapan individual. Selanjutnya, field key_from_me akan menunjukkah arah pengiriman pesan, di mana nilai 0 berarti pesan masuk sementara nilai 1 bermakna pesan keluar.

Di sisi lain, struktur basis data pada tabel wa_contacts berisikan gabungan grup dan pengguna individual dengan perbedaan terdapat pada field number, di mana grup berisikan <no.hp.admin>@s.whatsapp.net sementara pengguna individual hanya berisikan <no.hp.pengguna>. Selain itu, pengguna individual juga memiliki beberapa field tambahan yang berisikan data, yakni raw_contact_id dan status. Yang juga menarik adalah ditemukannya seluruh nomer telepon lain yang tersimpan dalam phonebook meski yang bersangkutan tidak terinstall WhatsApp, dalam hal ini ditandai dengan nilai " 0 " pada field is_whatsapp_user. Temuan ini dapat menjadi isu privasi tersendiri apabila ditemukan bukti lain bahwa WhatsApp juga mengunggah dan menyimpan semua nomer telepon ini ke server yang mereka miliki.

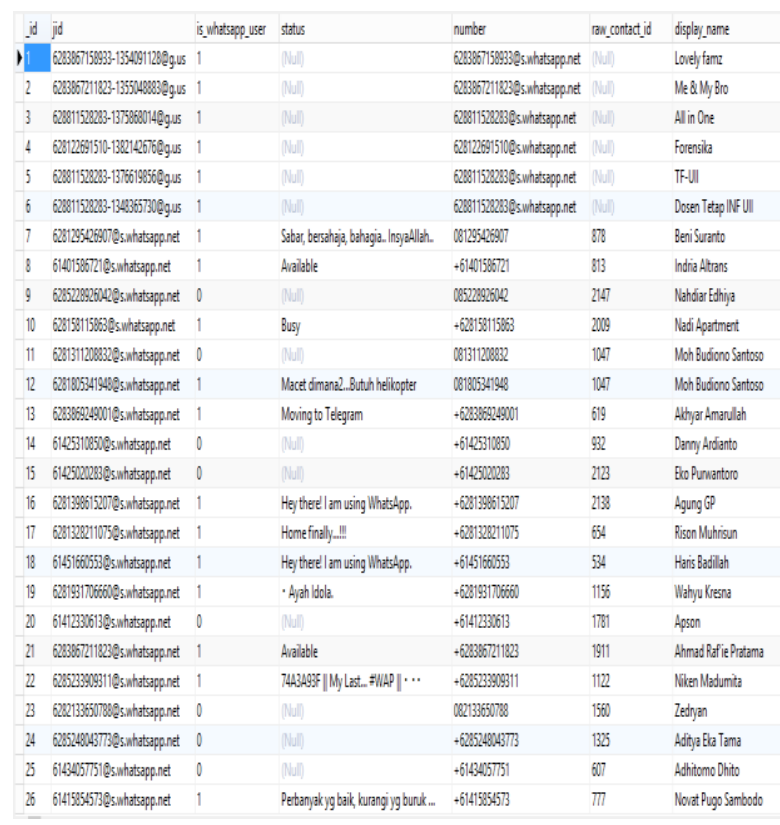

Gambar 9. Isi tabel wa_contacts pada basis data wa.db di platform Android

\section{EKSPLORASI PADA IOS}

Pada platform iOS, perangkat uji yang digunakan pada proses eksplorasi adalah telepon pintar iPhone 4 yang telah terpasang iOS 7.1 dan WhatsApp versi 2.11 .8 di dalamnya. Dikarenakan karakteristik sistem operasi iOS yang tertutup, folder aplikasi 
WhatsApp ataupun aplikasi - aplikasi lainnya tidak bisa diakses secara langsung hanya dengan menyambungkan perangkat uji ke sebuah PC. Gambar 10 menunjukkan bagaimana iOS hanya mengizinkan akses ke folder DCIM yang berisikan hasil screenshot, foto, dan atau video yang direkam melalui kamera ataupun didapat dari aplikasi lain.

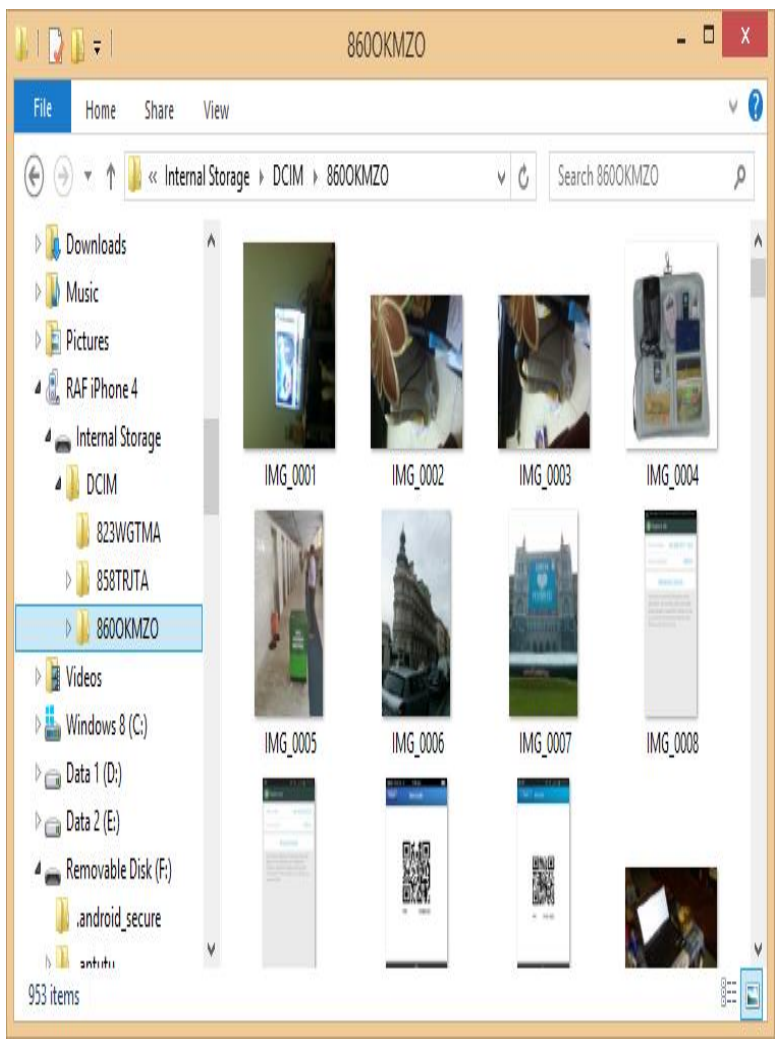

Gambar 10. Sistem berkas iOS berisi foto dan hasil screenshot yang dapat diakses melalui PC

Eksplorasi dilanjutkan dengan bantuan aplikasi iExplorer versi 3.2.5.2 Trial Mode yang dapat membaca sistem berkas iOS yang tidak bisa diakses dengan cara sebelumnya guna mengakses folder khusus dari masingmasing aplikasi yang terpasang, termasuk WhatsApp. Dari hasil eksplorasi didapatkan beberapa berkas multimedia (gambar 11) serta berkas basis data penyimpanan arsip pesan (gambar 12). Rekapitulasi lengkap sistem berkas yang ditemukan pada folder Apps $\backslash$ WhatsApp dapat dilihat pada tabel 3.

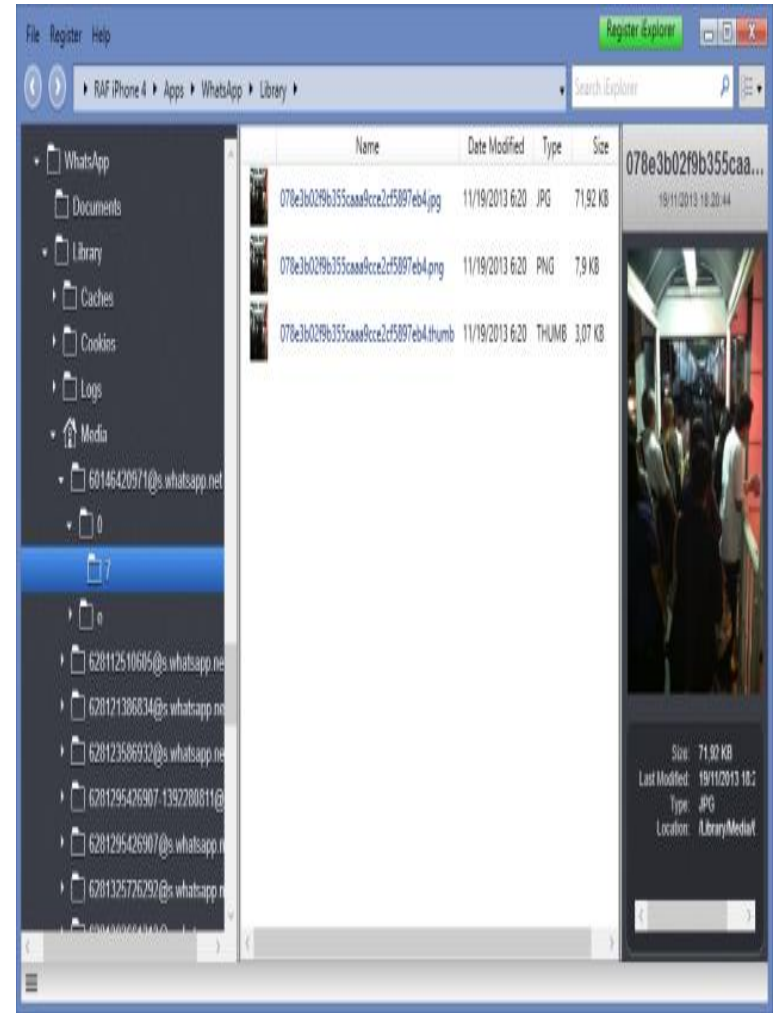

Gambar 11. Sistem berkas penyimpanan media pada WhatsApp di platform iOS

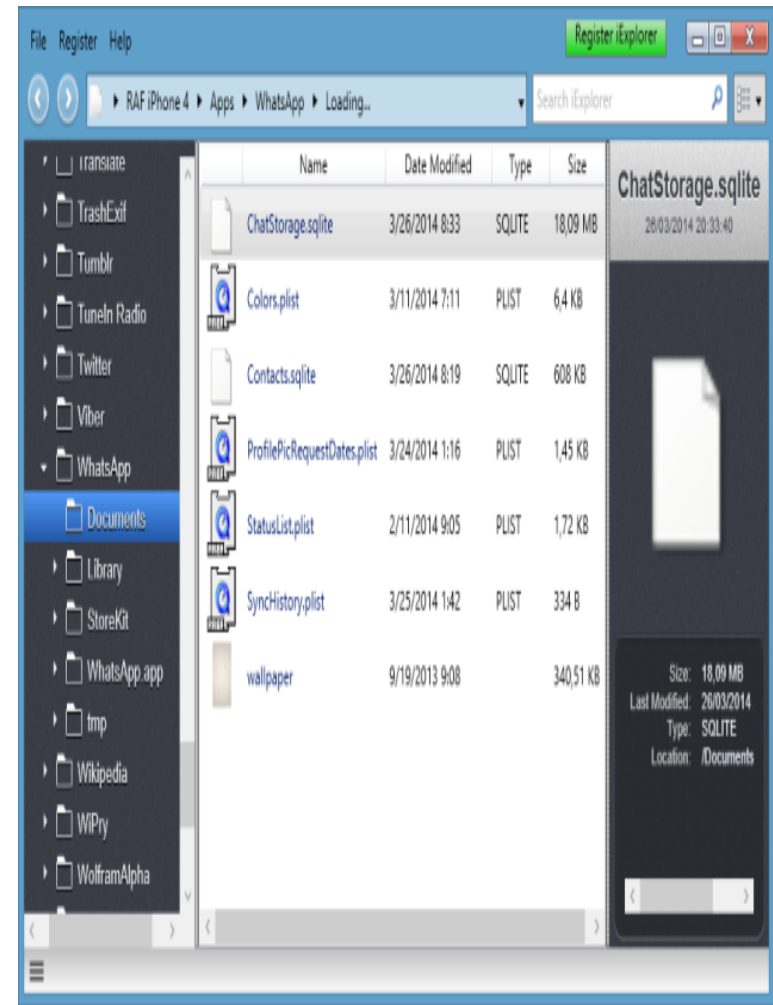

Gambar 12. Sistem berkas penyimpanan basis data pada WhatsApp di platform iOS 
Tabel 3. Sistem berkas yang ditemukan pada

\begin{tabular}{|c|c|c|}
\hline \multicolumn{3}{|c|}{ WhatsApp di platform iOS } \\
\hline No & Lokasi & Keterangan \\
\hline 1 & Documents & $\begin{array}{l}\text { Basis data arsip } \\
\text { pesan (.sqlite) } \\
\text { dan berkas } \\
\text { konfigurasi } \\
\text { (.plist) }\end{array}$ \\
\hline 2 & Library\Caches & $\begin{array}{l}\text { Snapshot, } \\
\text { Thumbnail, dan } \\
\text { beberapa berkas } \\
\text { lainnya }\end{array}$ \\
\hline 3 & Library\Cookies & Berkas cookies \\
\hline 4 & Library\Logs & $\begin{array}{l}\text { Berkas catatan } \\
\text { kejadian pada } \\
\text { aplikasi dan } \\
\text { koneksi dengan } \\
\text { server }\end{array}$ \\
\hline 5 & LibraryMedia & $\begin{array}{l}\text { Berkas } \\
\text { multimedia } \\
\text { (foto, video, dll) } \\
\text { yang disimpan } \\
\text { per pengguna }\end{array}$ \\
\hline 6 & Library $\backslash$ Preferences & $\begin{array}{l}\text { Berkas } \\
\text { pengaturan } \\
\text { global, termasuk } \\
\text { akun WhatsApp } \\
\text { yang terpasang } \\
\text { (.plist) }\end{array}$ \\
\hline 7 & StoreKit & $\begin{array}{l}\text { Receipt (bukti } \\
\text { pembelian } \\
\text { aplikasi dari } \\
\text { AppStore) }\end{array}$ \\
\hline 8 & $\backslash$ WhatsApp app & $\begin{array}{l}\text { Berkas penyusun } \\
\text { aplikasi (icon, } \\
\text { dll) }\end{array}$ \\
\hline 9 & $\backslash t m p$ & Kosong \\
\hline
\end{tabular}

Selanjutnya, eksplorasi dilanjutkan pada basis data yang ditemukan. Format basis data yang digunakan pada aplikasi iOS adalah SQLite versi 3, sama dengan format yang digunakan pada aplikasi Android, meski dengan ekstensi berbeda (.sqlite). Sama halnya dengan aplikasi Android, didapatkan juga dua basis data (ChatStorage.sqlite dan Contacts.sqlite) yang masing - masingnya memiliki tabel - tabel seperti yang tampak pada gambar 13 .

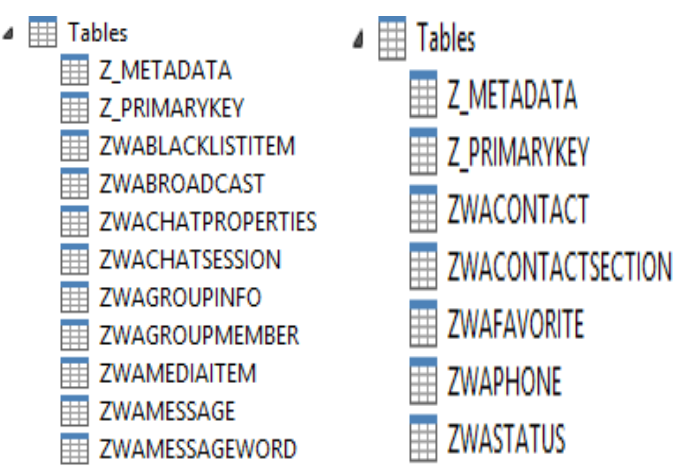

Gambar 13. Daftar tabel pada basis data ChatStorage.sqlite (kiri) dan basis data

Contacts.sqlite (kanan) pada WhatsApp di platform iOS

Struktur tabel ZWAMESSAGE pada basis data ChatStorage.sqlite yang menyimpan seluruh arsip pesan dapat dilihat pada gambar 14, sementara struktur tabel ZWACONTACT pada basis data Contacts.sqlite yang menyimpan seluruh kontak pengguna lain dapat dilihat pada gambar 15. Beberapa nama field memberikan informasi mengenai data apa yang disimpan, namun demikian untuk keperluan forensika tingkat dasar dapat disaring beberapa field tertentu dengan melakukan $S Q L$ query seperti yang tampak pada gambar 16 sehingga menghasilkan arsip percakapan seperti yang dapat dilihat pada gambar 17. Perbedaan struktur tabel yang dimiliki aplikasi iOS ini memungkinkan untuk melakukan penyaringan arsip pesan berdasarkan sesi percapakan sehingga menjadi lebih mudah untuk dibaca secara kronologis dan sistematis. 


\begin{tabular}{|c|c|c|c|c|c|c|}
\hline \# Name & Data type & $\mathrm{PP}$ & $F \cup$ & $\mathrm{HN}$ & C & Default value \\
\hline 1 Z_PK & INTEGER & ? & & & & NULL \\
\hline 2 Z_ENT & INTEGER & & & & & BULLL \\
\hline 3 Z_OPT & INTEGER & & & & & MULL \\
\hline 4 ZCHILDMESSAGESDELLVEREDCOUNT & INTEGER & & & & & MULL \\
\hline 5 ZFLLTEREDRECIPIENTCOUNT & INTEGER & & & & & MLLL \\
\hline 6 ZFLAGS & INTEGER & & & & & MULLL \\
\hline 7 ZGROUPEVENTTYPE & INTEGER & & & & & NULLL \\
\hline 8 ZISFROMME & INTEGER & & & & & MULL \\
\hline 9 ZMESSGGESTATUS & INTEGER & & & & & MLLL \\
\hline 10 ZMESSGGEETYPE & INTEGER & & & & & NULLL \\
\hline 11 ZSORT & INTEGER & & & & & MULL \\
\hline 12 ZBROADCAST & INTEGER & & & & & NULLL \\
\hline 13 ZCHATSESSION & INTEGER & & & & & MULL \\
\hline 14 ZGROUPMEMBER & INTEGER & & & & & MULL \\
\hline 15 ZLASTSESSION & INTEGER & & & & & MULL \\
\hline 16 ZMED|A|ATEM & INTEGER & & & & & MULL \\
\hline 17 ZPARENTMESSAGE & INTEGER & & & & & MULL \\
\hline 18 ZMESSGGEDATE & TIMESTAMP & & & & & MULL \\
\hline 19 ZFROMNDD & VARCHAR & & & & & MULLL \\
\hline 20 ZPJISHNAME & VARCHAR & & & & & NLILL \\
\hline 21 ZSTANZAID & VARCHAR & & & & & MULL \\
\hline 22 ZTEXT & VARCHAR & & & & & MULLL \\
\hline 23 ZTOND & VARCHAR & & & & & MULL \\
\hline
\end{tabular}

Gambar 14. Struktur tabel ZWAMESSAGE pada basis data ChatStorage.sqlite di platform iOS

\begin{tabular}{|c|c|c|c|c|}
\hline \# Name & Data type & $P F$ & U H N & C Default value \\
\hline 1 Z_PK & INTEGER & ? & & NULL \\
\hline 2Z_ENT & INTEGER & & & Blll \\
\hline 3 Z_OPT & INTEGER & & & WULL \\
\hline 4 ZBB USSERID & INTEGER & & & WULL \\
\hline $5 \mathrm{ZSORT}$ & INTEGER & & & MULL \\
\hline 6 ZSECTION & INTEGER & & & KULL \\
\hline 7 ZFIRSTNGME & VARCHAR & & & MULL \\
\hline 8 ZFULLNAME & VARCHAR & & & MUL \\
\hline 9 ZIMAGEHASH & VARCHAR & & & KWLL \\
\hline 10 ZINDEXNAME & VARCHAR & & & MUL \\
\hline 11 ZTOKENS & BLDB & & & WULL \\
\hline
\end{tabular}

Gambar 15. Struktur tabel ZWACONTACT pada basis data Contacts.sqlite di platform iOS

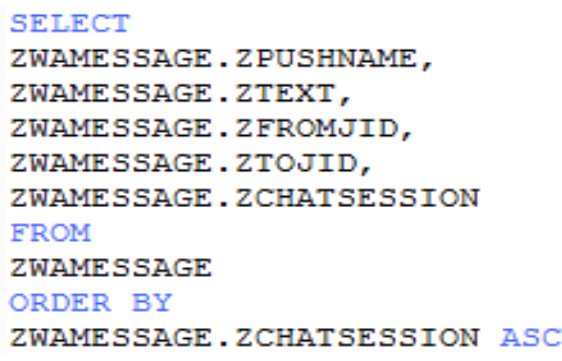

Gambar 16. Contoh $S Q L$ Query untuk menyaring arsip percakapan pada tabel ZWAMESSAGE pada WhatsApp di platform iOS

\begin{tabular}{|c|c|c|c|c|}
\hline VWANI: & $\mathbb{Z I E T}$ & BANOD & 7000 & ZCHWBSOH \\
\hline 4 & Utemgan & $\mid(14)$ & 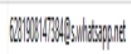 & $\xi$ \\
\hline (H) & 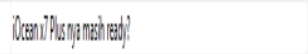 & ||$|u|$ & 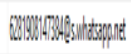 & 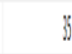 \\
\hline tha & V|äh & 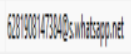 & & 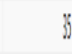 \\
\hline (in) & 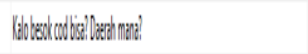 & (14) & 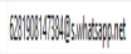 & $\xi$ \\
\hline 尡 & faciciated & 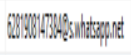 & & 8 \\
\hline (1) & 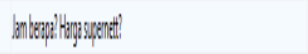 & || $4 \mid$ & 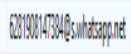 & $\xi$ \\
\hline twa & 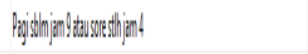 & 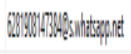 & & 3 \\
\hline Ha & 1|t:i2. & 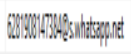 & & 3 \\
\hline $\mid(4)$ & Hagranged & $(\mid \mathrm{d})$ & 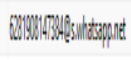 & j. \\
\hline itw & Gensiveswitin & 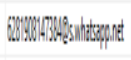 & & $\xi$ \\
\hline$|(1)|$ & 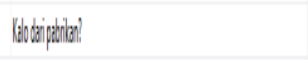 & $\mid$ |aid & 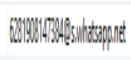 & $y$ \\
\hline 间 & Gersigarititon & 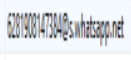 & & 8 \\
\hline$($ in) & 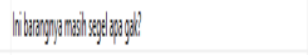 & (1A) & 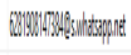 & $y$ \\
\hline the & 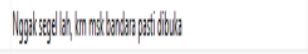 & 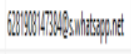 & & 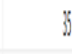 \\
\hline$($ (I) & 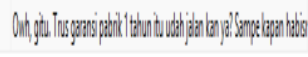 & & 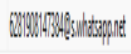 & $y$ \\
\hline PWHWWIE & $\operatorname{IBT}$ & BROND & Z0O10 & 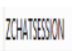 \\
\hline $\mathbb{1}$ & 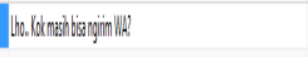 & $|(|⿰|)|$ & 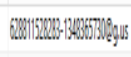 & \\
\hline hatili & 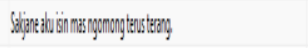 & 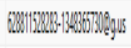 & & \\
\hline$(\mathrm{a})$ & 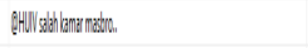 & $(\mathrm{H})$ & 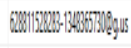 & \\
\hline matily. & 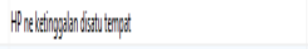 & 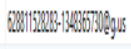 & & \\
\hline matik & 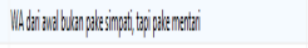 & 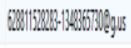 & & \\
\hline (vil) & 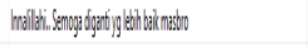 & (lii) & 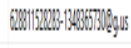 & \\
\hline bei & Hinien. & 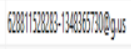 & & \\
\hline (Ni) & 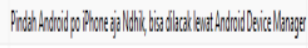 & & 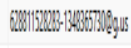 & \\
\hline coctonsmail & 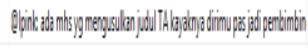 & 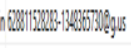 & & \\
\hline bei & 8 & 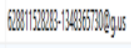 & & \\
\hline leygling' & 88 & 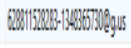 & & \\
\hline laylling' & KuiThifinnalla!" & 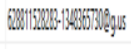 & & \\
\hline coctonsmandii & 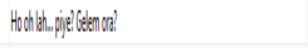 & 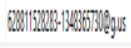 & & \\
\hline legylling' & thath. & 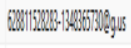 & & \\
\hline Vayyling' & Onuaiby & 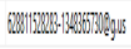 & 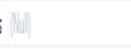 & \\
\hline
\end{tabular}

Gambar 17. Hasil SQL Query dari tabel ZWAMESSAGE berupa arsip percakapan individual (atas) dan grup (bawah) pada WhatsApp di platform iOS 
Eksplorasi yang dilakukan pada basis data Contacts.sqlite menghasilkan temuan struktur tabulasi yang lebih kompleks jika dibandingkan dengan basis data wa.db aplikasi Android. Penyimpanan kontak pada aplikasi iOS ini tersebar pada beberapa tabel, yakni tabel ZWACONTACT yang menyimpan nama pengguna disertai user ID nya (gambar 18) sementara nomer telepon yang digunakan tersimpan dalam tabel ZWAPHONE bersama dengan WhatsApp ID yang notabene berupa nomer telepon dengan kode negara di bagian depannya (gambar 19). Kedua tabel ini dihubungkan oleh sebuah field $Z \_P K$ yang menjadi primary key di keduanya.

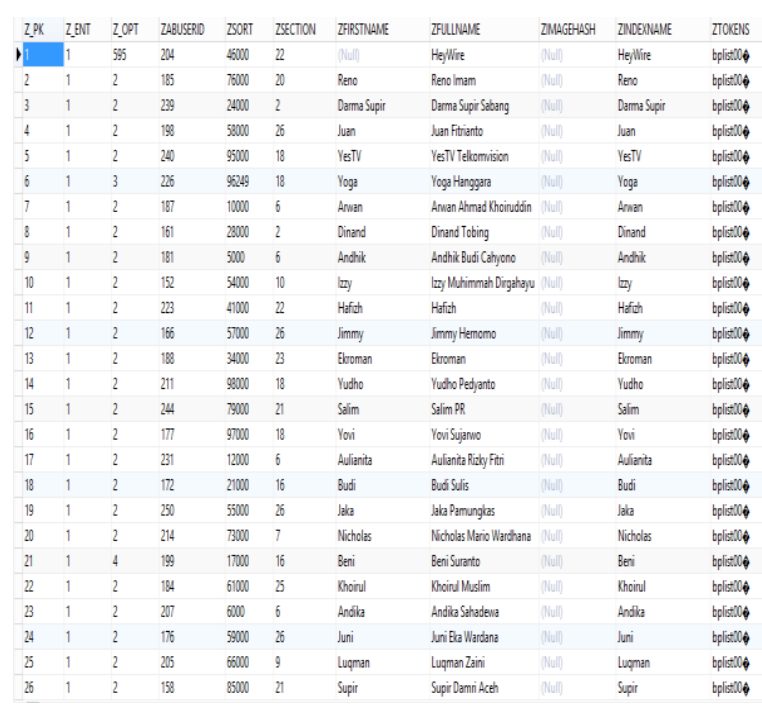

Gambar 18. Isi tabel ZWACONTACT pada basis data Contacts.sqlite di platform iOS

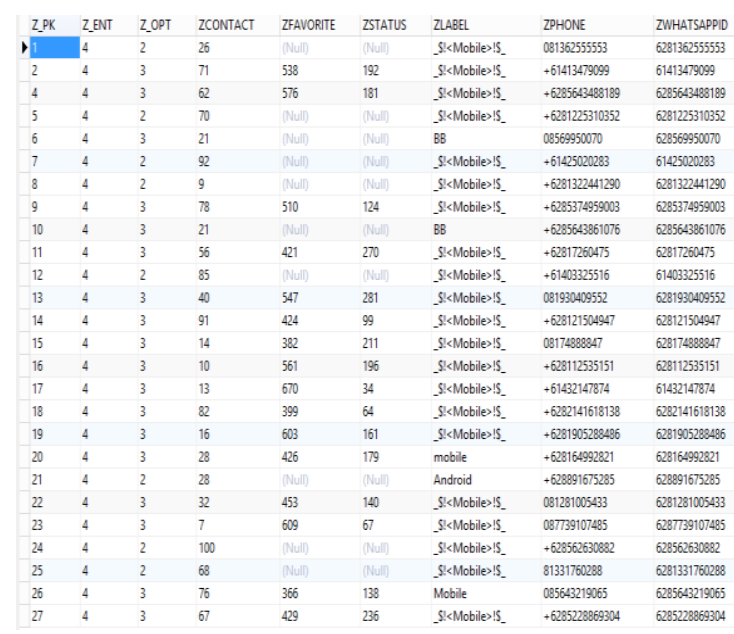

Gambar 19. Isi tabel ZWAPHONE pada basis data Contacts.sqlite di platform iOS
Selain dua tabel di atas, masih terdapat satu tabel lagi, yakni ZWASTATUS yang menyimpan status akun yang bersangkutan, dihubungkan dengan WhatsApp ID sebagai foreign key-nya.

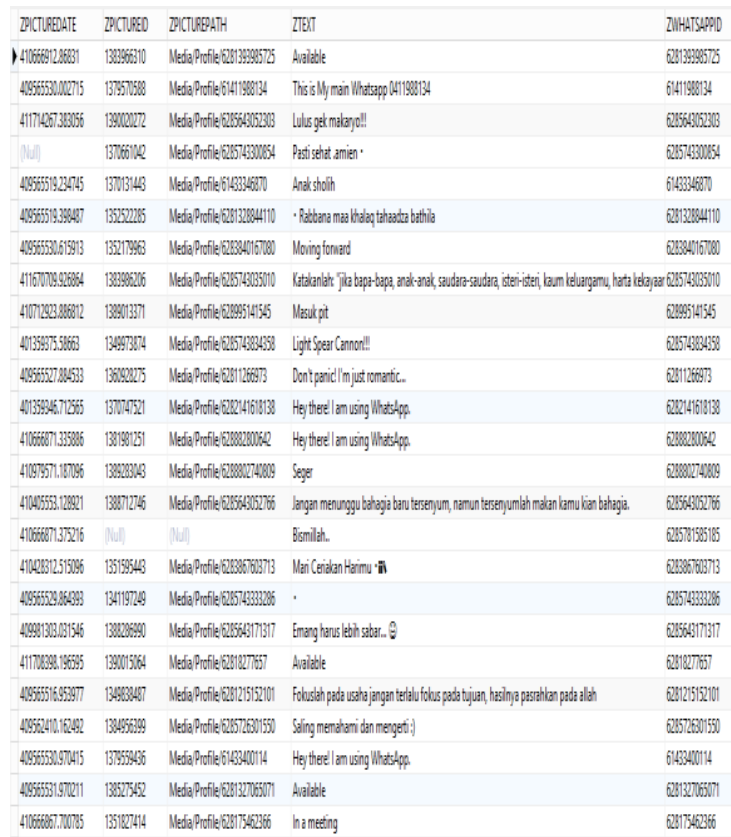

Gambar 20. Isi tabel ZWASTATUS pada basis data Contacts.sqlite di platform iOS

\section{KESIMPULAN}

Berdasarkan hasil eksplorasi yang telah dilakukan pada aplikasi WhatsApp di platform Android dan platform iOS, dapat disimpulkan beberapa hal sebagai berikut:

1. Berkas basis data pada aplikasi WhatsApp di platform Android tersimpan dalam format terenkripsi. Jika perangkat Android sudah memiliki hak akses root, maka basis data yang tidak terenkripsi dapat ditemukan dengan bantuan aplikasi file manager khusus semisal Root Browser atau yang sejenis, yang terpasang di perangkat Android bersangkutan.

2. Berkas basis data pada aplikasi WhatsApp di platform iOS tidak tersimpan dalam format terenkripsi. Namun demikian, karakteristik platform iOS tidak memungkinkan untuk mengakses berkas secara langsung tanpa bantuan aplikasi pihak ketiga, semisal iExplorer atau yang sejenis. 
Dengan bantuan aplikasi tersebut, berkas basis data dapat ditemukan tanpa mensyaratkan proses jailbreak pada perangkat berbasis iOS bersangkutan.

3. Struktur basis data yang dimiliki aplikasi WhatsApp pada perangkat berbasis Android berbeda dengan struktur basis data yang dimiliki aplikasi WhatsApp pada perangkat iOS. Pada platform Android, struktur basis data yang digunakan cenderung terpusat baik itu untuk arsip percakapan maupun kontak pengguna lain. Sementara itu pada platform iOS, basis data yang digunakan lebih terstruktur dengan rapi dan terdistribusi pada beberapa tabel yang berbeda dengan bantuan foreign key untuk menghubungkan tabel - tabel yang memiliki relasi.

4. Perbedaan struktur basis data aplikasi WhatsApp pada platform Android dan iOS tidak memiliki pengaruh besar mengingat informasi yang tersimpan tidak jauh berbeda. Konsekuensi logis dari perbedaan ini adalah cara query yang berbeda untuk menggali informasi yang sama di kedua platform yang berbeda ini.

5. Informasi utama yang bisa didapatkan dari sistem berkas aplikasi WhatsApp di media penyimpanan, baik pada platform Android maupun iOS adalah arsip percakapan disertai informasi lawan bicaranya serta berkas - berkas multimedia (semisal foto dan video) yang dikirimkan pada percakapan.

6. Penelitian ini membuka peluang untuk dilakukannya penelitian - penelitian lanjutan, baik itu terkait aktivitas WhatsApp forensics maupun aktivitas aktivitas lain yang relevan. Salah satu peluang yang dapat dilakukan adalah pengembangan aplikasi khusus untuk melakukan pembacaan berkas basis data WhatsApp yang dapat melakukan automatic query sesuai dengan hasil temuan pada penelitian ini agar dapat menyajikan arsip percakapan dari berkas basis data yang ditemukan layaknya tampilan pada aplikasi WhatsApp aslinya.
Selain itu, penelitian sejenis juga dapat dilakukan pada aplikasi pesan instan lainnya yang juga memiliki popularitas cukup besar agar dapat memberikan wawasan yang lebih luas yang dapat berguna untuk keperluan mobile forensics secara umum. Dengan adanya gambaran serupa pada masingmasing aplikasi yang berbeda, penelitian lain juga dapat dilakukan untuk membandingkan perbedaan karakteristik dari masing - masing aplikasi yang ada, baik dari sisi keamanan hingga kemudahan proses forensika yang bisa dilakukan dari masing-masing aplikasi tersebut.

\section{DAFTAR PUSTAKA}

Husain, M. I., \& Sridhar, R. (2010). iForensics: Forensic Analysis of Instant Messaging on Smart Phones. In Digital Forensics and Cyber Crime (pp. 9-18). Springer Berlin Heidelberg. DOI: 10.1007/978-3-642-11534-9_2

Killey, M., Danker, S., \& Rogers, M., (2008). Forensics Analysis of Volatile Instant Messaging. In Advances in Digital Forensics IV (pp. 129-138). Springer US. DOI: 10.1007/978-0-387-84927-0_11

Levendoski, M., et al. (2011). Yahoo Messenger Forensics for Windows Vista and Windows 7. Purdue University, US. Diakses dari http://www.cerias.purdue.edu/assets/sy mposium/2011-posters/7DD-26B.pdf

Mahajan, A., Dahiya, M.S., \& Shanvi, H.P., (2013). Forensic Analysis of Instant Messenger Applications on Android Devices. In International Journal of Computer Applications. Volume 68No.8, April 2013. DOI: 10.5120/116026965

Thakur, Neha S. 2013. Forensic Analysis of WhatsApp on Android Smartphones. Thesis. University Of New Orleans, US. Diakses dari http://scholarworks.uno.edu/td/1706/

Van Dongen, W. S. (2007). Forensic ArtefactsLleft by Windows Live Messenger 8.0. Digital Investigation, 4(2), 73-87. 